\title{
PARADOXIC LANGUAGE "CEBONG-KAMPRET" IN FACEBOOK AS A MIRROR OF THE POLITICAL LANGUAGE OF INDONESIA
}

\author{
Paradoks Bahasa “Cebong-Kampret” di Facebook sebagai Cermin Pertarungan \\ Bahasa Politik Indonesia
}

\author{
Fabianus Fensi \\ Program Studi Ilmu Komunikasi Universitas Bunda Mulia, Jakarta \\ Jalan Lodan Raya Nomor 2, Ancol, Jakarta Utara 14430
}

Diterima 20 Maret 2019 / Disetujui 20 September 2019

\begin{abstract}
Communication and language are two phenomena from one reality. Language is a means of expressing ways of communicating, and it reciprocally presupposes with communication. Where there is communication, language presence is demanded. Hence the language exists as a medium of communication. This study analyses the language battles of "Cebong-Kampret" on Facebook groups. Two aspects are investigated in this research: logic and ethics. The logic requires the use of language by rules. Language can be understood within the framework of rationality. Ethics requires language that creating peace rather than encouraging hatred. How is the language contested in the battle of "Cebong-Kampret" on Facebook? Facebook is a web-based media technology that has its characteristics, such as easily accessed and reach a wider audience. Everyone can be a creator of meaning. The communication process is synchronous and encourages the user's instant response. This characteristic carries risks. Facebook, in the political context of "Cebong-Kampret," is paradoxical. People's political preferences are influenced by Facebook even though the language ignores the logical-ethical language rules. The fight of language in politics is justified as far as upholding the logic and ethics. Logic language teaches the principles based on standards. Misuse of language logic makes language lose its ethical value in practice. Language ethics teaches the principles of good language, which can create peace.
\end{abstract}

Keywords; Language; Logic and Ethics; Social Media; Paradox; Politics

\begin{abstract}
ABSTRAK
Komunikasi dan bahasa adalah dua fenomena dari satu kenyataan. Komunikasi menyertakan bahasa. Bahasa sebagai alat mengekspresikan berbagai cara berkomunikasi. Bahasa dan komunikasi saling mengandaikan. Dimana terdapat kegiatan berkomunikasi bahasa dituntut kehadirannya. Bahasa hadir sebagai media ekspresi aktivitas komunikasi. Kajian ini menganalisis pertarungan bahasa kelompok "Cebong" dan "Kampret" di facebook. Dua aspek dianalisis, yaitu logika dan etika berbahasa. Logika berbahasa mensyaratkan penggunaan bahasa menurut kaidah sehingga bisa dimengerti dalam kerangka rasionalitas. Etika mensyaratkan penggunaan bahasa yang menciptakan perdamaian bukan mendorong kebencian. Apa yang terjadi dengan bahasa yang dipertarungkan "Cebong" dan "Kampret" di facebook? Facebook adalah media berbasis teknologi web. Dia memiliki karakteristik sendiri, seperti: Dapat diakses dengan mudah. Menjangkau khalayak lebih luas. Setiap orang bisa menjadi pencipta makna. Proses komunikasi berlangsung sinkronik. Mendorong respon instan penggunanya. Karakteristik ini mengandung risiko. Penggunaan facebook, dalam konteks politik "Cebong" dan "Kampret" bersifat paradoks. Preferensi pilihan politik masyarakat dipengaruhi facebook padahal bahasa yang digunakan mengabaikan aturan berbahasa secara logis-etis. Pertarungan bahasa dalam politik dibenarkan sejauh menjunjung tinggi logika dan etika berbahasa. Logika berbahasa mengajarkan prinsip berbahasa berdasarkan aturan. Penyalahgunaan logika berbahasa membuat bahasa kehilangan nilai etis dalam praktiknya. Etika berbahasa mengajar prinsip pemakaian bahasa yang baik. Bahasa yang baik menciptakan perdamaian.
\end{abstract}

Kata Kunci; Bahasa; Logika dan Etika; Media Sosial; Paradoks; Politik.

*Korespondensi Penulis:

E-mail: ffensi@bundamulia.ac.id 


\section{INTRODUCTION}

We realize that communication and language are like two sides of a coin. We cannot possibly understand one without the other. Communication is not possible without the presence of an expression tool of language, and the language that cannot be interpreted as a means of expressing thoughts, ideas, longings, hopes, and interests if it does not work as a communication tool.

It is no exaggeration that the presence of language and communication always assume one another. Where there are activities in communicating languages, their presence is demanded. Language is used as a tool to express the various ways and styles of people to communicate. Its existence requires the other's existence. Not separate, but influences and influences the overall social context of community life.

This study tries to analyze the patterns of language struggle between "Cebong" and "Kampret" on Facebook in Indonesian political practice (Behnke, 2010:120). The research centres on the logical-rational and ethical language system. As a social reality, politics cannot possibly avoid the existence of social media as another social reality (Adelia, Diponegoro, Tembalang, \& Berita, 2019:174). We all know that social media is the closest media that we utilize all the time. Various matters, from private and individual to social, including politics, use social media as a reference.

The language used by social media, especially Facebook, is also varied. It is ranging from formal languages to new languages created by social media themselves and presented in full and ready to use. With its flexible characteristics, social media is no longer bound by the standard rules of language and considers the language rules are no longer critical. The most crucial factor is the effort of communicating messages to the public.

That is what happens in politics. Language and political relations are not relationships that appear suddenly. For thousands of years, it finally has been truly realized how the reality of language and political practices influence each other (Zuhro, 2019:70).

Chilton (2004) even emphatically saying that language and politics are evolving together (co-evolution) (Ridwan, 2013:124).
Political actors use the language to influence their political messages to audiences. They are very aware of language importance in their political actions. They also must be able to package political words with attracting language that persuades the public.

In Indonesia, the use of social media can be considered as paradoxical (Alatas \& Sutanto, 2019:166). It means that, on one side, social media, with its behavior of ignoring language rules, is used as a people's political preferences on the other side. Or, in another meaning, our contemporary political language is strongly influenced by social media even though we understand that social media languages often disregard the good (logical-rational dimension) and proper (ethical dimension) language rules.

Social media develops with its own rules. Based on the working principle that emphasizes the instinct of freedom, social media can create its own language. This condition is indeed hazardous, not only in the agreed linguistic order but also in the politics of language in daily communication. Another danger is that an act of language that was initially produced by a crowed group (gangs) may turn into a shared language in society. When a wrong language has become a universal language reference, then at the same time, logic-rationality and language ethics are at stake.

Here, we emphasize that the language struggle in political communication is legitimate, and even justified. Democratization found its operational form of maturity in the effort of egalitarian language. However, we must also emphasize that the struggle for democratic language is justified so far as it gives an ample space to logicalrational principles and language ethics at the same time. Both of these principles must serve as a corrective instrument to the politics of communication with civilized languages.

We must say that the ethics of language in political communication teaches the principle of using language, which is not only valid according to logical-rational principles, but also ethically appropriate. Good language in politics creates peace, and the logic of language in political communication teaches the principles and rules of language based on specific regulations. Misuse of language rules and logic makes a language lose its ethical value in itself. The political language of communication, which ignores ethical and 
logical principles, only produces rude political practice.

\section{THEORETICAL BASIS}

\section{Language and Politics}

The history of language and political relations can be considered as an intimate relationship (intimate link) (Ridwan, 2013:123) and must be put at a fundamental level. According to Aristotle, whose aware of this intimacy, in a Policy (political representation of the state), people live together in harmonious order with all living beings, but what distinguishes is that humans possess the power of speech.

Speech in terms of language, according to Aristotle, is an individual's ability to share common views within the Policy, both regarding useful and also harmful matters such as social justice and injustice. All of them are discussed so that the state as a household can stand on the same voice.

Plato asserted that politics and language must be harmonized to ensure compatibility between human existence and the overall structure of the belief system's ontology and the beliefs of its people.

According to Plato, the language used in politics must be able to perform as a tool to gain strength and influence public beliefs. Plato also reminded that as a tool, the language also could be used to manipulates politics. However, of all things, according to Plato, political language must always be directed to the process of political stability and rationality of community structure.

As an evolutionary phenomenon, there are at least two points of view which implicates the idea about the relationship between language and politics (Ayuningtias \& Hartanto, 2014:25-27). The first point of view emphasizes the language that evolved from a random generic mutation process whose existence is beneficial for human development. Language is not something that is embedded as the nature of the human brain. Language is independent, difficult to predict, but affects everything.

The second point of view says that language evolved from primate brain structures. It can be depicted as social intelligence, which provides the basis for language development. Social intelligence, in its pure form, takes a specific model from the initial development of the human brain. Various theories of language were born from this perspective. Language has a social function from the beginning. The concept of "someone that united with someone" itself already shows relationships, coalitions, and social hierarchies. Anthropology scientists call it a social phenomenon, a stage of thought that seems to be a political phenomenon as well.

These two ways of thinking bring important implications for all studies of linguistics and communication in the modern community. Grice views that various theoretical debates around the approach to meaning in language have underlined the importance of human communication. According to Grice, the use of language and political practices work together. The structure of language in communication expressly acknowledge the possibility to interact with various political actions (Ayuningtias \& Hartanto, 2014:25-27).

\section{Political Language and Ethical Norms}

Various agreements, norms, and assumptions in the language of communication are always relevant to defining individual knowledge into the language process materially. The effects of knowledge and various efforts to interpret interests and desires are called as the political behavior of the language. The political behavior of language is seen as the full truth of the human communication process. The language of communication in the social scope of human life should allow all forms of persuasion logic as well as an opponent of those persuasions as a reality of the cycle action communication.

The question is, why does language selection occur in political communication? The truth of communication behavior depends not only on the usefulness of information but also on the accuracy of it. Accurate information affects how someone is receiving or rejecting information. A piece of new information is considered valid if its accuracy can be accepted.

The Marxist-based linguistic and political thinker of the 20th century, Noam Chomsky, sharply criticized American foreign policy, calling it a foreign policy that ignored the principle of equality. One of Chomsky's controversial stance is when he analyzes the relationship between language and politics and puts it in the framework of an anarchist political philosophy form. 
According to Chomsky, admirers of anarchistic politics always places humans as rational individual beings. He can regulate himself without requiring the involvement of any external authority. Language is seen as a form of innate knowledge which has a particular scheme. Individuals are always assumed to be free, whether to occupy social space or not, without any pressure from the authority of power.

To summarize, Chomsky's political language thinking can be explained in two aspects. First, language skills and structures are seen as creative processes. Politics or ethical principles already contain this process in themselves. The generative form of creativity from language is freedom for all humans. In this case, the appreciation and principle of language equality become a fundamental axiom.

Second, the language clearly by itself functions as a medium of communication. Language is no longer essential to be associated with structure, and the important thing is the linguistic function. According to Chomsky, language is not only associated functionally with communication. More than that, language becomes a propaganda tool in the socio-political process of society. In other words, language and politics evolved together.

\section{Language and Political Action}

Based on the writings above, can language influence, or rather determine the certainty of someone's thought and action? The assumption is that ideas and actions are influenced by language (Edward Sapir). Edward Sapir emphasized that the formal characteristic of every language is to regulate every type of conception of the world. And it is assumed that everyone has it. It also means that language governs everyone's way of thinking.

At the grammatical and lexical level, language is used as an expression's reflection, which means that language is placed at the level of interaction between the individual's utterances with the interpretation of the language. At the practical level, language is used for various purposes. That same language plays a very decisive role not only in the process of human socialization but also for the formation of specific conceptual frameworks in his life.
The social and political system is related to the process of interaction. Every concept formation always presupposes language as a vehicle of understanding. The concept is formed by nothing else but language. Language facilitates social and political practice. No one talks about politics or ethics without being tied to the system of using language as practical action.

Another question will emerge regarding what constitutes ideal free communication. This question is not a matter of language from the purely linguistic side, but rather a question from the social theory side of language. Jurgen Habermas introduces this understanding. The assumption is that every thought must depart from the commitment of language analysis to political orientation as a discourse.

Chomsky stated that the social commitment of language is to encourage reflection on the use of language in the level of freedom of society. Or that language always refers to social norms and honesty which expresses itself from the wearer. The social agreement of the people primarily determines the meaning of a language. It is not surprising that Habermas calls language "universal pragmatics" and Chomsky calls it "universal grammar" (Syamsiyah, 2017:6869).

Habermas asserted that in society, ideally, language is used freely by anyone. And, communication purposes are often distorted by particular interests and measures. Thus born what Habermas called an ideal speech situation (Syamsiyah, 2017:68).

The theoretical study of language and politics can be controversial in practice. However, first, we need to emphasize that political language and behavior can be understood as fundamental cognitive contributions to the development of thought and more than just social practice. Second, language and all social behaviors are closely related. Both are the same as innate mechanisms or developmental mechanisms as a result of evolutionary adaptation. Third, the relation of human language and various social forces are not relations that do not influence each other. Language must be connected with human cognitive power to encourage the building of criticism and free critical action.

It must be reminded that, on the one hand, a language in a social context must interact with various individuals in a group. 
But, on the other hand, language is a picture of the actual state of society. Or, language expresses interaction's meaning as well as the meaning of representation of the picture of its people. In this case, two approaches might be taken: one using a practical descriptive instrument, the other using a review of the text, a political text, and all political utterances (Syamsiyah, 2017:59).

\section{Political Communication}

Politics, in a strict sense, is a process of communication. By following Harold Laswell's way of thinking, politics does not stand alone but involves political actors, policies (political messages), audiences (people) who are named in politics, the media as a propaganda tool, and also a flashback process on how politics is carried out. Or, in the context of communication, Dan Nimmo (Sundoro, 2018:45), quoting Mark Roelofs, stated that politics is actually like communication because it involves talks. And talks are (mostly) politics.

Brian McNair (Hamad, 2004:21) simply limits political communication in three contexts: First, political communication is limited in the context of all forms of communication used by politicians and all other political actors in achieving specific goals; Second, communication is addressed to non-political actors, such as voters and newspaper columnists; Third, political communication is related to the context of the activities of the actors, including activities to deliver news, editorial activity, and all forms of media discussion regarding political activities.

Effective political communication always requires the involvement of the media as a propaganda tool. In other words, it is impossible for a communication process in political activities to succeed without utilizing the presence of the media. The development of the media today not only massively influences political behavior but also the media plays politics through the process of framing events that they broadcast to the public. The public is also given a different interpretation space for an event reported.

\section{Social Media and Politics}

One of the massive developments in contemporary media today is the development of social media. This web-based media technology can be accessed easily; reach a wider audience; everyone can be a creator of meaning; synchronous communication process; and encourage users' instant response through written comments and editing/changing the content of an event. (Zuhro, 2019:71)

Characteristics of social media are not uncommon to be used as mouthpieces for various political activities. Social media is useful as a communication tool: connecting activists, unite them, facilitate their interaction processes, and mobilize them to participate and involve in various social and political movements. The stability of social media (Facebook, Twitter, E-mail) is mobilized for the benefit of political campaigns and mobilizes community participation at the grassroots level.

Like the influence of social media everywhere, in Indonesia, social media can be seen as an arena for language struggle in politics. On one side, politics and language are embedded in one matter. On the other hand, politics and social media language is a different matter. The development of social media in Indonesia was born in conjunction with post-Soeharto social and political reforms. The technological revolution took place evolutionarily (Zuhro, 2019:80). Political activists, especially the student movement on campuses, first used pager technology in the 1990s to improve their communication with one another. Then between 1990-1995, computer technology began to develop. The ease of computers is used as a tool of political struggle.

Furthermore, the technological revolution gave rise to e-mail, which became a model of change in everyday communication in Indonesian society. And recently, the technology saw the development of social media, websites, and blogs. Almost all politicians, academics, and various movement groups use social media platforms such as Facebook to expand their communication networks. Facebook was then seen as an alternative to the new publication model, in addition to newspapers, magazines, newspapers, and books as the mainstream media.

Anders C. Johnsson (2016: 3) illustrates that to communicate, most Indonesian social media users have a strong tendency to utilize three major international social media, such as Facebook, Twitter, and WhatsApp. This study illustrates that $44 \%$ of social media 
users in Indonesia are young, aged around 20 to 29 years old.

This segment will prove that the language of social media influences politics. The history of the massive movement of the use of social media in politics in Indonesia dates back to the 2012 DKI Jakarta Governor election and continues to the 2014 legislative and presidential elections (Anders C. Johnsson, 2016: 26-32). Supporting politicians and political parties utilize social media, not only as a campaign tool to increase the choice of candidates being promoted but also to conduct policy and political debates (Pudjantoro, 2015:138). With the widespread use of social media, it is no exaggeration that the use of social media with various existing platforms, such as Facebook, Twitter, Yahoo Messenger, and Blackberry Messenger are considered an integral part of the democratic process in Indonesia.

We know that social media has different characteristics from mainstream media. The Encyclopedia of Social Media and Politics mentions several fundamental characteristics of social media such as: organized technology, a self-image, develops organically, conveys messages in a short, direct, sometimes extreme form of personal attack, encourages a model or context of communication, often appears in various political games, often exploits people's emotional sensitivity, spontaneously presents instant things including expressions of beliefs, opinions, observations, and experiences, and prioritizes the creative element of an event.

These characteristics have their dangers. It takes a common standard to use the language of social media in politics. Peter Farb, quoted by Dan Nimmo, said that talking through a language is nothing but a game. The game requires a player. Similarly, language requires players. And, anyone who is near the game will undoubtedly involve themselves in the game even with a different playing style (Sundoro, 2018:55). This cluster wants to imply a demand for the application of ethical principles in a game, including language games.

Social media as an arena for democratic battles where the language play is possible must be involved in specific ethical calculations, so that, borrowing the language of Dan Dimmo, his behavior does not violate politeness, does not harm, and does not even act violently (Sundoro, 2018:55). Democracy does require freedom of speech, but freedom of language rationally refers to proportional ethical standards. Perju (Perju, 2013: 1046) said that freedom always considers the principle of protecting individual rights as a basic principle every time we talk about that freedom. Ignorance of ethical demands can make language prone to conflict at the social level.

This study focuses on the conflict, or more precisely, the language struggle on Facebook, which is often used by two opposing sides of political support of Indonesia's presidential candidates: Joko Widodo and Prabowo Subianto, which on one hand is used as a mockery between camps, but on the other hand, the language they use is precisely strengthen their support identity. This study is oriented towards language examination on social media of Facebook, especially concerning the rational and logical dimensions of language.

\section{RESEARCH METHOD}

This research utilizes a qualitative research method with a critical-interpretative paradigm. Qualitative research is an exploratory method and seeks to understand a meaning, which by several individuals or groups of people, is considered to originate from social and humanitarian problems (Creswell, 2010: 4). This method has several procedures: collecting specific data, inductive data analysis, and interpreting the meaning of data.

Qualitative research is subjective because it assumes that knowledge does not have an objective and permanent nature, or is universal, but is interpretive. Human behavior is contextual because it is formed by the meaning they give to their environment. Social reality is fluid and quickly changes through interaction. Social phenomena are temporary and multi-meaning, and it is always assumed that negotiations will take place to determine the status of reality (Mulyana, 2013: 32-38).

With a critical paradigm, this research is intended to reveal, on the one hand, the pattern of the use of the language "Cebong" and "Kampret" in the era of media freedom, especially social media, especially Facebook. 
On the other hand, this paradigm dismantles ways of how logical rational and ethical principles are ignored, but it is precisely used in language, especially when we consider the social and political plurality of society.

\section{RESULT AND DISCUSSION}

Based on "ts history, the term "Cebong" and "Kampret" strengthened, even tended to be harsh, after the 2014 presidential election. Initially, the term "Cebong" was used by the "anti-Jokowi" to refer to the supporters of President Joko Widodo. The word "Cebong" was initially used as a mockery that referred to President Joko Widodo's fondness for raising tadpoles.

Similarly, the term "Kampret" initially was used by Jokowi's supporters to refer to the defeat of the Koalisi Merah Putih (lit. red and white coalition) (KMP) who supported the presidential and vicepresidential candidate of Prabowo SubiantoHatta Rajasa in the 2014 presidential election. Initially, the KMP was read as "Ka-eM-Pe. But to cause a painful and even cornering effect, they modified "Ka-eM-Pe" with the name of "Kampret" (lit. bats).

The two terms that originally mediocre have transformed into a language battle. The fight went hard on the social media of Facebook. Its use by opposing groups causes offense and even anger from other groups.

We also see that the terms of "Cebong" and "Kampret" do not have a denotative meaning relationship with the explicit meaning according to the dictionary. The implication is built symbolically (implicitly) based on the references of the supporters of each party. It is used as a form of ridicule for each other.

As a comparison, its meaning can be traced through the KBBI (lit. Large Indonesian Dictionary) (Hamid, Darwis, \& Andriyani, 2018:29). KBBI refers the "Cebong" as tadpoles. According to the same dictionary, tadpoles are defined as frogs that are still in the fish-like state (have gills) and have a large quantity in the puddles, and bats are insect-eating small bats and their nose folds in pools (Anto, 2018).

In its development, each supporter expanded the understanding of the tadpole and bats. For supporters of Joko Widodo, the term 'tadpole' is now no longer considered a painful mockery and, on the contrary, a matter of pride. They call themselves the natural evolution of the tadpole from the original tadpole, the tadpole of the original race, and the true tadpole (Hamid, Darwis, \& Andriyani, 2018:32). True tadpoles are those from political parties who support honest and good politics and politicize without distinguishing others because of ethnic, racial and religious backgrounds (Anto, 2018).

"Cebong" and "Kampret" can be explained as a unique unit in the rhythm and dynamics of Indonesian politics. Displays most of the characters that are almost the same, but only the characters that look hard are shown on social media of Facebook. The similarities seen in interactions: does not want to budge, has the ability of viciously attacks he opposition, militants, in favor of hoax, easily-triggered emotion, and place their idols on a more superior position than their opponents'. (Anto, 2018).

More lenient in behavior that has similarities, but in different characters, the two sides are "as if" battling in an arena of war. Both of them are very loud. These include the characteristics of the "Cebong" group: economically well-established with a relatively high educational background, very militant, moving independently, fought hard on Facebook, using data-based attacks or counter-attacks, using factual arguments, and staying away from hoaxes. However, they are too fanatical, so they tend to be blinded by their main idol (Jokowi), and they assume that their idol is never wrong.

While the characteristics of "Kampret" are seen in behaviors such as: always being in one line of command because it is strong and not easily swayed, aggressive on social media, engaging in provocation behavior, producing bombastic news that tends to be a hoax, posting old photos with new narrative, producing images that are not related to the narration, and defend groups exposed to legal cases such as SARACEN and MCA (Anto, 2018).

We can actually say that the similar characteristics of those two groups are also their differences (Anto, 2018). The war between them took place virtually on social media of Facebook through diction, the use of provocative language, and tend to ignore the general rules of language in mass media in general. 
The following are two examples of Facebook languages: the language of conflicting interests of tadpoles and bats. The author does not analyze contexts outside the logical and ethical dimensions of language (such as the semiotic meaning of images) but focuses on the development of language adherence to language rules and whether the language is good when written for public consumption.

The author deliberately took and analyzed two examples of the language used by this group from Facebook. Because, in general, the language they use is more or less the same as the sound of the language that the writer took/chose. Or, this language sample is used as a sample analysis only.

The following are two examples of languages that will be analyzed in this study. First, the language of the Cebong group, "KEBAYANG KALAU WOWO YANG JADI PRESIDEN, ACARA LEVEL INTERNASIONAL BAKAL DIISI DANGDUT KOPLO. GITU KO NGAKU MACAM ASIA." (lit. Imagine of Wowo (Prabowo) Becomes President, International Events will have the Dangdut Koplo Music. How Dare He Claim Himself as the Tiger of Asia?) The author accesses the following picture from Facebook on July 21, 2019:

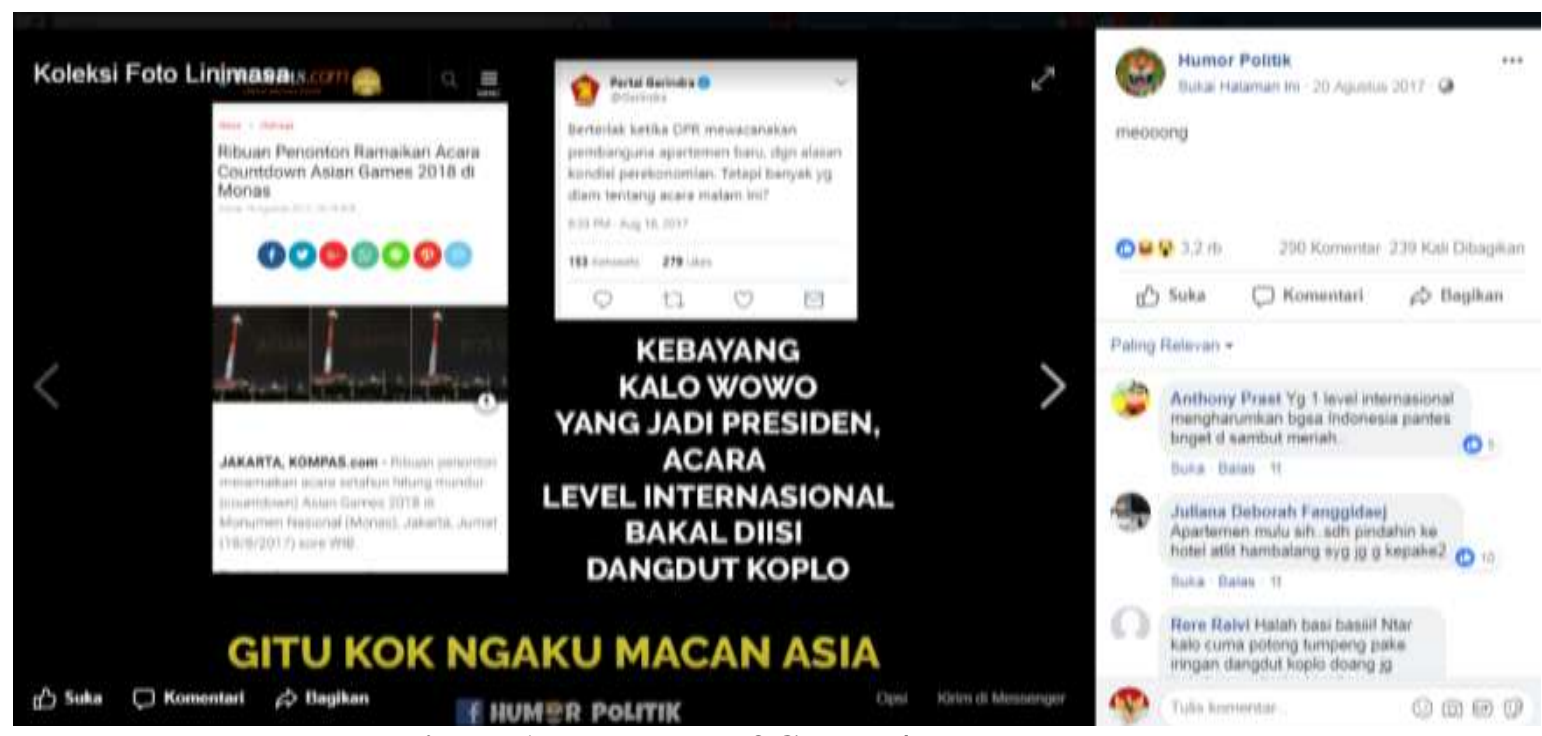

Figure 1: Language of Cebong/Tadpoles group

Source: Facebook, accessed 21 July 2019

Secondly, the language of the Kampret group, "Bahas import glla'an, balesnya tol ..., Bahas pertumbuhan ekonomi nyungsep, balesnya tol ..., Bahas serbuan TKA, balesnya tol ..., Bahasa ketidakadilan hukum, balesnya tol ....., Bahasa janji2nya yang mbelgedhes semua, balesnya tol ..., Bahasa penistaan agama, balesnya tol .... Mereka pikir hidup bernegara cukup dengan tol ... Padahal tol fungsinya cuma buat kendaraan, itu pun harus bayar ... Dasar Cebong Otak Aspal”. (lit. Discuss crazy import, he replies with toll road ..., discuss collapsing economic growth, he replies it with toll road ..., discuss the invasion of foreign workers, he replies with toll road ..., discussing legal injustice, he replies with toll road ..., discussing his bullshit promises, he replies with toll road ..., discussing blasphemy against religion, he replies with toll road ... They thought that living in the country was sufficient with a toll road ... Even though the toll road was only for vehicles, it had to pay .... You tadpoles have a brain of Asphalt!). The following images are accessed, 21 July 2019: 


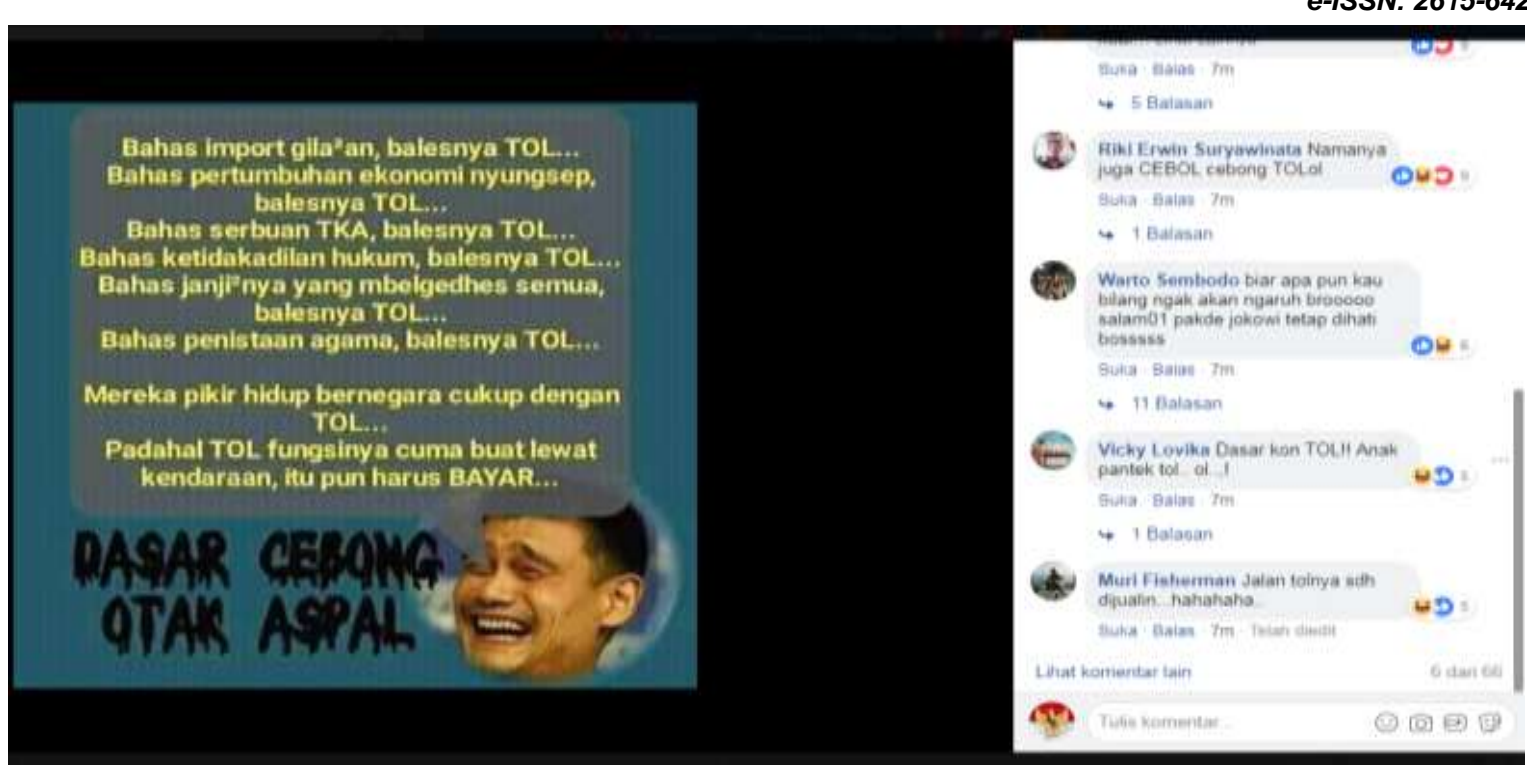

Figure 2: Language of Kampret/Bats group

Source: Facebook, accessed 21 July 2019.

These two language samples taken and selected will be discussed / analyzed with two approaches, namely the logical-rational approach and the ethical-normative approach.

\section{Discussion}

We must emphasize that patterns of language use and political practice in a country cannot be seen as overlapping with one another, but rather an entity that works with one another.

Following Grice's view, we must say that the structure of language used in politics always recognizes the possibility of interaction with various political actions (Bentley, 1995:21-23). So the language in this case is not just a tool but he is the act itself.

J.L. Austin (1911-1960), who published the theory of speech act, saying that "when we state something, we are not only putting together words (syntactic), or expressing certain meanings (semantics), but we are presenting actions certain through our words" (Rosidah, 2015:156).

According to him in one statement, or even in an article, we are doing several actions at once, namely: Locutionary Act, Illocutionary Act, Perlocutionary Act, and Interlocutionary Act.

Locutionary Act, means the act of expressing the contents of a statement, or showing the reality of what is to be said or spoken through a language; Illocutionary Act, means the act of language to express all feelings, thoughts, hopes, and longings when someone states the reality that would be conveyed to others. The Illocutionary Act shows itself in the way someone says something; Perlocutionary Act, meaning the act of language that directly affects the listener through the utterance of someone who is spoken; Interlocutionary Act, which means the act of communicating with others, simultaneously through spoken words.

Political actions expressed through ideal language, as recommended by Jurgen Habermas (Bentley, 1995:28-29), not entirely ignored by social media, like Facebook. Ideally, every utterance, whether written, spoken, or uttered in public space, must at least contain two ideal conditions at once: rational language and ethical language.

Rational language is intended as a language that can be logically accepted by the public because its systematic flow touches reason to be understood. Ethical language is designed to be a form of language that is spoken or written publicly acceptable because politeness and its effects do not break public cohesiveness.

Both of these language models are called ideal because, on the one hand, the rationality of language assumes the truth of a language not distorted by the interests of language creators and users. On the other hand, language ethics believes that a language created (written) contains the power of integrating different socio-political interests around the process of creating and using a language. 
The language of social media, especially Facebook, in the context of the battle of the "Cebong" and "Kampret" (Tadpoles and Bats) in Indonesian politics, can be seen as a phenomenon that deliberately distorts the ideal of language as a medium for disclosing factual truths and ethical ideals to build national unity.

Although Grice said that the use of language and political practices supported each other, we must say that language design that deliberately avoids the truth gave birth to hoax-dimensional language production (Bentley, 1995:21-23). And also, language design that ignores ethics and norms gives birth to language production in the dimension of defamation and fighting. This tendency is not only dangerous for the preservation of a growing democratic climate but also hurts the existence of a civilized and socially just nation

This is the naked phenomenon of the political language struggle between Cebong and Kampret. The following will describe two examples of languages used by the group of "Cebong" and "Kampret". The two languages are analyzed using two approaches, namely language logic and language ethics. The two examples of languages described above will be analyzed one by one.

\section{Language Logic}

Logic is always understood in the context of procedures, laws, and methods of how the human mind is organized. Logic thus deals with two things, namely the right or wrong of a construction of the way humans think. The question is, what is the logical construction of the language of the group "Cebong" and "Kampret" on Facebook? We see a language struggle in sentences written on Facebook, both by the "Cebong" group and the "Kampret" group. It appears that the language written by the opposing group was immediately replied to by other opposing groups. Just look at the following two sentence sentences: "KEBAYANG KALAU WOWO YANG JADI PRESIDEN, ACARA LEVEL INTERNASIONAL BAKAL DIISI DANGDUT KOPLO. GITU KO NGAKU MACAM ASIA." (lit. Imagine of Wowo (Prabowo) Becomes President, International Events will have the Dangdut Koplo Music. How Dare He Claim Himself as the Tiger of Asia?)
At first glance, this sentence is more categorized as a ridiculing tone of style from Jokowi's supporters towards Prabowo's supporters. This sentence is not necessarily left spread throughout the universe of Facebook. Prabowo's supporters did not stay silent. They responded with language that was no less harsh, as quoted below:

"Bahas import gila'an, balesnya TOL ..., Bahas pertumbuhan ekonomi nyungsep, balesnya TOL ..., Bahas serbuan TKA, balesnya TOL ..., Bahasa ketidakadilan hukum, balesnya TOL ...., Bahasa janji2nya yang mbelgedhes semua, balesnya TOL ..., Bahasa penistaan agama, balesnya TOL .... Mereka pikir hidup bernegara cukup dengan TOL ... Padahal TOL fungsinya cuma buat kendaraan, itu pun harus BAYAR ... DASAR CEBONG OTAK ASPAL". (lit. Discuss crazy import, he replies with toll road ..., discuss collapsing economic growth, he replies it with toll road ..., discuss the invasion of foreign workers, he replies with toll road ..., discussing legal injustice, he replies with toll road ..., discussing his bullshit promises, he replies with toll road ..., discussing blasphemy against religion, he replies with toll road ... They thought that living in the country was sufficient with a toll road ... Even though the toll road was only for vehicles, it had to pay .... You tadpoles have a brain of Asphalt!)

Let's examine the battle of these two sentences. During the examination of this mockery language, it seems like ignoring a theoretical assumption that the political behavior of language is seen as full truth if it is seen as human communication. It means that language becomes true when he can greet everyone who reads it humanely.

Both languages, or specifically, sentences, not only oppose the theoretical assumptions about political behavior in language but also against other theoretical assumptions, namely that the language of communication in the social sphere of human life should allow all the logic of persuasion to operate as part of the act of communication.

The communicative action echoed by Habermas wants to direct language and political communication to the elimination of the building blocks (Arditama, 2016: 80) when we talk about public space.

Facebook is a public space. According to Scott Wright, when a person/group of people communicates, and their 
communication is hampered by the problem of language that is not comprehensively logical, public space cannot be considered as "exist." The logic of Facebook language, as quoted above, not only concerns the language game, where the language is intentionally reversed but also fails to build a conclusion that can be rationally justified.

Examine this language of this "Cebong" group: "Kebayang kalau Wowo yang jadi Presiden. Acara level Internasional bakal diisi Dangdut Koplo. Gitu ko ngaku macan Asia". (lit. Imagine of Wowo (Prabowo) Becomes President, International Events will have the Dangdut Koplo Music. How Dare He Claim Himself as the Tiger of Asia?)

In this sentence contained a conclusion, "Gitu ko ngaku macan Asia" ("How Dare He Claim Himself as the Tiger of Asia"). However, this conclusion is not logically drawn from two premises, namely the premise, "Kebayang kalau Wowo yang jadi Presiden" (Imagine of Wowo (Prabowo) Becomes President), and the other premise "Acara level Internasional bakal diisi Dangdut Koplo" ("Events will have the Dangdut Koplo Music").

Or, try to examine the logic of thinking from the "bats" group in the following sentences, "Bahas import glla'an, balesnya tol ..., Bahas pertumbuhan ekonomi nyungsep, balesnya tol ..., Bahas serbuan TKA, balesnya tol ..., Bahasa ketidakadilan hukum, balesnya tol ...., Bahasa janji2nya yang mbelgedhes semua, balesnya tol ..., Bahasa penistaan agama, balesnya tol .... Mereka pikir hidup bernegara cukup dengan tol ... Padahal tol fungsinya cuma buat kendaraan, itu pun harus bayar ... Dasar Cebong Otak Aspak" (Discuss crazy import, he replies with toll road ..., discuss collapsing economic growth, he replies it with toll road ..., discuss the invasion of foreign workers, he replies with toll road ..., discussing legal injustice, he replies with toll road ..., discussing his bullshit promises, he replies with toll road ..., discussing blasphemy against religion, he replies with toll road ... They thought that living in the country was sufficient with a toll road ... Even though the toll road was only for vehicles, it had to pay .... You tadpoles have a brain of Asphalt!).

This sentence contains a clear conclusion, which is: "Mereka pikir hidup bernegara cukup dengan tol ... Padahal tol fungsinya cuma buat kendaraan, itu pun harus bayar ... Dasar Cebong Otak Aspak" (They thought that living in the country was sufficient with a toll road ... Even though the toll road was only for vehicles, even you had to pay for it .... You tadpoles have a brain of Asphalt!"). The problem is, the conclusion of this sentence is drawn from the many premise of criticism that "as if" the success of a nation is measured by toll development alone.

We check that the essential arrangement of premises is correct, not only in terms of how to structure the flow, the law, and the logical procedure for argumentation but also in the substance of criticism. However, unfortunately, the logical flow and substance of the criticism was damaged by a very rash conclusion, namely: "Padahal tol fungsinya cuma buat kendaraan, itu pun harus bayar" ("Even though the toll was only for vehicles, you had to pay for it").

The logic is simple: that the "vehicle" always presupposes the existence of a person (passenger), the vehicle cannot walk alone. The toll is a paid facility. Everywhere using toll roads must pay. That is how the logic plays. This means, by this simple logic, it is possible that the substance of the critic can get the stage.

Based on the two quotations and logical analysis above, we must firmly say that the conclusive way of thinking built by the two groups in these two statements of criticism is not only wrong, according to the legal rules of logical thinking, but also correlatively related to premises that cannot be accounted for.

Those statements lead to a very dangerous conclusion. We all know that language is not just a tool but also an action or encourages an action. We must also realize that language becomes dangerous, at the same time because of words and actions.

So, in this context, we agree with Habermas that in communication, language functions beyond, not just "reaching" understanding, language also plays an important role to directly coordinate various good actions from different subjects as the same media is used for purposes socialization (Prasetyo, 2012:168) or language as a medium for understanding as well as a media for coordinating the actions and socialization of individuals in a communicative society (Prasetyo, 2012:169). 
Thus the logical urgency of language not only cannot be found in these two sentences but also cannot provide adequate affirmation for anyone who reads to understand and comprehend the language in a logical-rational context.

\section{Language Ethics}

The next question is, how to deal with the language of the Toadpole and Bats that is taking place in the ethics area? Ethics always helps with anyone involved. Starting from the point of view of language then acting on the basis of ethics, then decides to use spoken language. From a variety of literature on ethical studies, we thoroughly understand the moral judgment with good and bad morals.

This is another problem. What was meant by the tadpoles group when writing "Acara level Internasional bakal diisi Dangdut Koplo. Gitu ko ngaku macan Asia?" ("The international level event will be filled with Dangdut Koplo. How can $\mathrm{He}$ called himself asian tiger?")? In terms of normative ethics, this sentence contains two condescending tendencies; the first, dangdut "Koplo" is considered as a form of "plebeian" entertainment because it feels funny and is considered "not classy" to be displayed at international events. Second, the entire context of this sentence tends to denigrate Prabowo as a person.

The word "Asian tiger" is an allegory style that describes a dominative power in a positive sense. However, this positive depiction was embezzled by the use of "Dangdut Koplo," which deliberately reduced the figure of Prabowo, whose by his supporters considered a candidate capable of returning Indonesia so that it could be respected in Asia.

This figurative portrayal of this pejorative model gives rise to a contradictory interpretation, from the "Asian tiger" as a symbol of positive force transforming into merely a degrading effect, in terminology, "Dangdut Koplo." Ethically, the act of degrading people with all forms of association is never justified.

The ethical ignorance model is also contained in sentences used by the Bats group. The important question is, what is the meaning of the phrase "asphalt brain Tadpoles"? The word "asphalt" refers to "toll road." However, the problem is, why are Tadpoles called asphalt brains?
Like the Tadpoles, the Bats also used a pejorative style of language to describe the uncritical behavior of Jokowi's supporters. For them, the success of building a toll road does not necessarily illustrate the overall success of the government. According to them, the construction of the toll road was deliberately exaggerated the Tadpoles to drown many other problems experienced by the nation at this time.

They mentioned: imported sugar, low economic growth, employment invaded by foreign workers (TKA), legal injustice, unfulfilled promises, and blasphemy of religion are the main problems of the nation. Those problems are claimed to be deliberately diverted because of the exaggeration narrative of toll road construction.

In terms of ethics, the use of the word "asphalt brain" is demeaning in two senses, at the same time, namely: first, the asphalt itself is an object and has no brain, how could the human brain be analogous to asphalt? It is a severe form of abuse. Second, asphalt brain is a form of pejorative to describe uncritical behavior. Support cohesiveness is built without rational consideration but is based on a sentimental and emotional attitude that is banal in nature and even tends to construct through the blinded support.

This is the real battleground for Facebook ethics. Do we need specific normative standards as the ideal language of social media? We need to underline that the various agreements, norms, and assumptions in the language of communication are always relevant for defining individual knowledge into the language process materially. The effects of knowledge and various efforts to interpret interests and desires are what we call the political behavior of the language.

Thus, the truth of communication behavior not only depends on the usefulness of the information or whether the message received by the audience but also depends on good/bad, accuracy, or the truth of information. Good, accurate, and correct information influences whether someone accepts or rejects that information. New information contains the truth and goodness if everyone can accept its accuracy (Bentley, 1995:22).

\section{Social Conflict Language as Pathology}

The emergence of social media, mainly Facebook, indicates a change in our society, 
both in communication and movement patterns. And, usually, changes bring a shock to the level of the national society, even the world. Not only when individuals see and determine society but also society or the world itself determines individuals acting, behaving, and thinking.

Changes with the ambition of modernity not only have an impact on the world as a place of information but also affect the world as a set of individual values with claims of autonomy's subjectivity. According to the author, this is the most dramatic cycle of conflict. It is when the dialectic of change determines the individual and society in shaping the world. And on the contrary, the world shapes the behavior, ways of acting, and thinking of individuals and their societies. That is precisely what happens to changes in language style and communication using social media communication platforms in politics, as explained above.

Otomar J. Bartos dan Paul Wehr (Bartos \& Wehr, 2002:6) said that conflict and change are inherently born simultaneously in the social world. So according to them, the conflict and change is a permanent pathology that is used, not only to organize society but can also destroy and annihilate it.

Social conflict is the history of the formation of society. Meaning that since society was formed at that time, the social conflict also became a part. The discovery of Newton's laws of physics, for example, directly produces opposing reactions in the history of theories in social science. Immanuel Kant (1724-1804) through his philosophical project of criticism and Georg Wilhelm Friedrich Hegel (1770-1831) through his dialectical project, according to Otomar J. Bartos and Paul Wehr help individuals, groups, and various social units to be critical of using conflict as a means of managing society in a better and dignified manner. What is the real question of social conflict? Why it become a pathologist in the world of social media in general, and Facebook in particular?

Quoting Burton, Ho-Won Jeong (Abdullah \& Syahartijan, 2018:6) said that social conflict is a severe change in a particular context, which is interpreted as an effort to strengthen norms, relations, and rules in decision making. In its broader form, conflict is always compared to one of the most concentrated forms of competition. In a conflict, two or more social entities are always associated with at least one type of antagonistic interaction.

According to Otomar J. Bartos and Paul Wehr, conflicts occur because each actors utilizes conflicting behavior against each other to achieve incompatible goals and/or to express their hostility (Bartos \& Wehr, 2002:13). Karl Marx (1818-1883) defines conflict as a conflict of interests between the capitalist class and the working class. The capitalist class has the interest of capital accumulation to accumulate as much wealth as possible by exploiting the working class, while the working class has the interest of earning wages by selling labor. Or in other words, conflict is the history of class struggle in the history of the development of capitalist society.

According to Ralf Dahrendorf, every group in the community has incompatible interests and goals, but they are not aware of it, which giving rise to a broader scale of conflict, let alone each of them (1) has a leader who causes the conflict; (2) has ideological conflicts; (3) has freedom to create conflict; and (4) having a communication model which influences conflict (Muttaqin, 2012:5).

According to Dahrendorf, social conflict continues to gain momentum if: (1) each member has incompatible goals; (2) high conflict over solidarity; and (3) conflicts occur if there are not enough (limited) resources to be obtained (Bartos \& Wehr, 2002:70).

The question is, why does social conflict become a pathology when it is staged on social media such as Facebook? From the beginning, we knew that social conflict does not always mean the conditions full of chaos. But instead, it is needed to organize society better. Social conflict requires a rational resolution. From the various conflict studies literature, we know that conflict requires resolution as a solution that can be accepted by all parties.

There are approximately four main concepts of conflict management as a solution, including negotiation, mediation, facilitation, and reconciliation (Putri, Madjid, \& Silitonga, 2019:31-42), which Habermas called it a "consensus." Can language consensus be built in the context of social media such as Facebook? This is what we 
find in this study. Based on the two approaches used (logic and language ethics), we cannot find a rational and ethical consensus on the language in question. Language precisely distorts due to loss of rationality and normative ethical values, primarily if we refer to the ideal consensus of communicative society.

If we agree with the concept of social conflict as an essential part of the history of the development of society, then we must also agree that social conflict must be overcome by building mutual consensus. Based on that, we must say that social conflict without rational consensus is what is called pathology, and that is what happened to the language used by Tadpoles and Bats groups on Facebook.

A rational consensus can only be reached in an intelligent society that has succeeded in satisfying communication. Satisfactory communication occurs precisely when each participant tries to understand an intention in attempting to reach a claim of validity. And these validity claims are rational so that they are accepted without coercion as a result of community consensus (Arditama, 2016:77). According to author, the nature of conflict management is acceptable, both rationally and ethically.

\section{Political Interest of Language}

We must recognize that the process of twisting the language of social media, especially Facebook, is carried out by actors to prioritize specific political interests and intentions. Who are these actors, and for what purpose are they willing to sacrifice the language dignity to be twisted in such a way as to have a degrading effect? Now the mass communication model is shifting in shape. Traditional mass communication (newspapers, television, radio) is experiencing digital transformation through the power of the internet. Communication takes place interactively. Now the line between mass media communication and forms of internet communication is blurred (Machmud, 2012:59).

There is an extraordinary shift from mass communication to what now is called mass self-communication. Mass selfcommunication is used by political actors to build a positive image on social media. In the case of the language battle between the Tadpoles and Bats groups, the actors appear associatively, meaning that they never appear as individual actors, but represent a whole group of support.

By calling Tadpoles, people must associate it with the whole group of supporters of President Joko Widodo. Likewise, when mentioning Bats, associative thinking patterns are directly directed at the entire supporter groups of Prabowo Subianto.

This associative dichotomy takes place naturally based on the respective categories of political interest. The political pattern of labeling from one group to another is seen as a necessity and not an ethical demand that must be avoided. And, even the operationalization of Machiavelli style politics is sternly allowed to take place (Andriani, 2012:116).

According to the writer, the phenomenon of language battle between Tadpoles and Bats groups on Facebook cannot be separated from the ways of the interests of subduing ethics and truth. If Machiavelli says, "the end justifies the means," the author says, "the interests justify all means."

Stanley Bing said that political interests must be reached, even in extreme ways. "Very good. Very cruel. If you beat it, you beat it as hard as possible. If you have fun, have fun as much as possible. If we are angry, we are really angry." Based on the logical and ethical analysis described above, we can say that the Tadpoles and Bats groups are both admirers of Machiavelli (regardless of whether they realize or not). They always nurture a group of organized enemies and foster hatred seriously.

This is politics. Language is contested by him to win interest in power alone. According to Habermas, this is a crisis (Muttaqin, 2012:7), which is a disruption to system integration that will ultimately threaten lives by betting social integration. Social integration is at stake because all the norm structures obtained through consensus are intentionally destroyed so that the community is threatened by moral disorder (anomie). According to Habermas, in a crisis, social institutions are threatened with disintegration. This nation is at stake in the way we understand political interests and how to obtain those political interests in society. 


\section{CONCLUSION}

Communication and language are interdependent. Communication always involves language as a medium of expression. Conversely, language has a particular meaning only when it is communicated. Without language, communication is meaningless, or even nothing. Likewise, in the case of communication, without language, communication does not have any form in the social realities of society. Although they are interdependent, they are different things. Language is one thing, and communication is another.

Language problems become interesting when they are drawn into specific areas of communication. Language is also interesting when used in different contexts. Language becomes interesting to discuss when it is produced and used in a way that interferes with the ethical stability and norms of living together. And language is interested in being discussed when the expression uses social media, such as Facebook and the like. This paper reflects some critical conclusions relating to the format of the language designed by social media, Facebook, especially its use in politics.

First, politics is the social reality of people's lives. Politics is a battleground for various interests (power) and become an unavoidable reality. Its existence is determined by human nature as a social being that demands to live with a nation or country by nature. Accordingly, the structure of society, citizens, and people of a nation are determined by how the political system is run. Thus, it is true that politics is called the inevitability of a given history.

Second, politics always demands political actors. They are the leading players. Good or bad and right or wrong politics as a system is primarily determined by how the players demonstrate on how to play politics. As a system, politics is not only good, but it is needed. However, many people become apriori with politics, not because of the system, but because of the way political actors playing with the system. One element that is easily used by political actors is manipulating language.

Third, language as a medium for expressing political messages. Good or bad and right or wrong politics is made possible by language communication messages.
Political actors are well aware of language as a tool that can be used to win battles. Politics as an arena of interests requires the use of language models to smooth out wining or losing results in a battle.

Fourth, social media (Facebook) as a battlefield for language has "zero" logic and ethics. The case of "tadpoles" and "bats" groups, it is a representation of logical and ethical nihilism in language. Language is associatively used to win groups of interest and to beat the other groups. Dialectics of friends versus opponents makes the language of Facebook unattractive to create cohesiveness to build togetherness. Language is manipulated to demean and create a negative stigma for those who choose a different political course.

Fifth, tadpoles and bats groups design political propaganda on Facebook by degrading the principles or rules of a logic language. They compile statements not to arrange the logical principles demanded by the correct language usage system but deliberately arrange the language to cause emotionally painful effects. The language constructed by the tadpoles and bats groups is designed not to build awareness of the facts but to a pragmatic goal of exploiting the sentimental and emotional dimension of the opponent. This is called language degradation.

Sixth, interests of damaging language. Political language is a pragmatic language, meaning that it is only used to achieve instant results. The language of pragmatic politics is not directed at building long-term plenary powers but wins five-year "mandatory" rituals. The academic theoretical basis of language is no longer essential, it has never even been understood as the fundamental power of building a political system in a state, but the language is designed merely as a servant to the ruling desire of political actors. A reality that endangers the integrity of society.

Seventh, the reconstruction of logic and language ethics to build a civilized society. Here, the author wants to repeat what was written before that the language struggle in political communication is legitimate, even if it is justified. Democratization precisely found the operational form of maturity in the struggle for egalitarian language. However, we must also emphasize that the effort for democratic language is justified in so far as it 
gives ample scope to ethical principles and language logic. Both of these principles must serve as corrective instruments to the politics of communication with civilized language.

Eighth, our political language on social media is experiencing an acute crisis. Habermas's warning that a crisis is a disruption to system integration that threatens our life should be a significant consideration in language. The social integration of this nation is at stake. Conscious or unconscious of the language of political actors on social media such as Facebook is deliberately designed to destroy the integration of the nation. If we agree with Habermas's way of thinking, then the language battle on social media is leading the nation's children to the brink of division. Will the crisis of this fight resulting in disintegration? Let us answer honestly.

\section{REFERENCES}

Abdullah, M. Z., \& Syahartijan, L. O. M (2018). PERAN ASEAN DALAM PENYELESAIAN KONFLIK ROHINGYA (STUDI KASUS PADA KONFLIK TAHUN 2012-2017). Jurnal Ilmu Komunikasi UHO: Jurnal Penelitian Kajian Ilmu Komunikasi \& Informasi, 3(4), 1-32. https://doi.org/10.1017/CBO978110741 5324.004

Adelia, O., Diponegoro, U., Tembalang, K. U., \& Berita, P. (2019). PENGGUNAAN MEDIA SOSIAL OLEH WARTAWAN JAWA POS. Interaksi Online, 7(3), 171-182. Retrieved from https://ejournal3.undip.ac.id/index.php/i nteraksi-online/article/view/24156

Alatas, S., \& Sutanto, V. (2019). Cyberfeminisme and Female Empowerment through New Media. Jurnal Komunikasi Pembangunan, 17(2), 165-176. https://doi.org/https://doi.org/10.29244/j urnalkmp.17.2.165-176

Andriani, C. K. (2012). KEPUASAN KERJA PIMPINAN DALAM LINGKUNGAN UNIVERSITAS NEGERI PADANG. Jurnal Kajian Manajemen Bisnis, 1(1), 113-127.

https://doi.org/10.1017/CBO978110741 5324.004
Anto, K. (2018). Karakter Cebong dan Kampret dalam Konstelasi Politik Indonesia. Retrieved from PepNews.com website: https://pepnews.com/2018/04/27/karakte r-cebong-dan-kampret-dalamkonstelasi-politik-indonesia/

Arditama, E. (2016). Politik Indonesia Indonesian Political Science Review. PENYELESAIAN SENGKETA PT. SURYA PERSADA LESTARI DENGAN MASYARAKAT KOTA PADANG GUNA MENJAGA STABILITAS KEAMANAN WILAYAH, $\quad$ l(1), 69-86. https://doi.org/10.15294/jpi.v1i1.9181

Ayuningtias, D. I., \& Hartanto, E. Ci. S. (2014). Pidato Politik di Indonesia: Sebuah Kajian Wacana Kritis. Prosodi, VIII (1)(1), 25-38. https://doi.org/https://doi.org/10.21107/ prosodi.v8i1.284

Bartos, O. J., \& Wehr, P. (2002). Using Conflict Theory. In Cambridge University Press. https://doi.org/10.1080/0163437090291 4448

Behnke, P. (2010). Social Media and Politics: Online Social Networking and Political Communication in Asia (P. Behnke, Ed.). Retrieved from http://www.kas.de/wf/doc/kas_215911522-1-30.pdf?110112080104

Bentley, R. K. (1995). Language, Politics and Order in Plato's Political Thought: A Study of Four Platonic Works (London School of Econonic \& Social Science). Retrieved from http://etheses.lse.ac.uk/2834/1/U615783 .pdf

Creswell, J. W. (2010). Mapping the developing landscape of mixed methods research (2nd ed.; A. Tashakkori \& C. Teddlie,

Eds.). https://doi.org/10.4135/9781506335193

Hamad, I. (2004). KONSTRUKSI REALITAS POLITIK DALAM MEDIA MASSA (Studi Pesan Politik Dalam Media Cetak Pada Masa Pemilu 1999). Makara Human Behavior Studies in Asia, 8(1), 21. https://doi.org/10.7454/mssh.v8i1.77

Hamid, A., Darwis, \& Andriyani, S. (2018). Fenomena Politik Cebong dan Kampret 
di Indonesia: Sebuah Analisis dari Perspektif Pemikiran Politik dalam Islam. Jurnal Politea, I(1), 29-36. Retrieved from https://www.google.com/url?sa=t\&rct=j $\& \mathrm{q}=\&$ esrc $=\mathrm{s} \&$ source $=$ web $\& \mathrm{~cd}=1 \& \mathrm{cad}$ $=$ rja\&uact $=8 \& v e d=2$ ahUKEwiroKuSiM HlAhW-

73MBHQBdAiEQFjAAegQIAxAC\&url $=\mathrm{http} \% 3 \mathrm{~A} \% 2 \mathrm{~F} \% 2 \mathrm{Fjournal}$. stainkudus.a c.id\%2Findex.php\%2Fpolitea\%2Farticl e\%2Fdownload\%2F4320\%2F3048\&usg $=\mathrm{AOvVaw} 2 \mathrm{~s}-0 \mathrm{~W} 3 \mathrm{E} 1 \mathrm{IIv} 2 \mathrm{uCtj} \mathrm{A}$

Machmud, M. (2012). Perkembangan Teknologi Dalam Industri Media. Jurnal Teknik Industri, 12(1), 57-64. https://doi.org/10.22219/jtiumm.vol12.n o1.57-64

Muttaqin, A. (2012). Agama Dalam Representasi Ideologi Media Massa. KOMUNIKA: Jurnal Dakwah Dan Komunikasi, 6(2), 1-9. https://doi.org/10.24090/komunika.v6i2. 349

Perju, V. (2013). International constitutionalism and the state: A reply to Aoife O'Donoghue. International Journal of Constitutional Law, 11(4), 1046-1051. https://doi.org/10.1093/icon/mot050

Prasetyo, A. G. (2012). Menuju Demokrasi Rasional: Melacak Pemikiran Jürgen Habermas tentang Ruang Publik. Jurnal Ilmu Sosial Dan Ilmu Politik, 16(November 2), 168-185. https://doi.org/https://doi.org/10.22146/j sp.10901

Pudjantoro, P. (2015). Sikap Kritis Dan Keterampilan Berargumentasi. Jurnal Pendidikan Pancasila Dan Kewarganegaraan, 28(2), 137-144. https://doi.org/http://dx.doi.org/10.1797 7/jppkn.v28i2.5455

Putri, N., Madjid, M. A., \& Silitonga, T. B. (2019). Dispute Resolution of Pt. Surya Persada Lestari With Communities in Padang City To Maintain Regional Security Stability. Jurnal Damai Damai Dan Resolusi Konflik, 5(2), 27-52. Retrieved from http://jurnalprodi.idu.ac.id/index.php/D RK/article/view/355/pdf

Ridwan, M. (2013). Komunikasi Politik dan
Diplomasi Berbasis Kearifan Lokal dalam Masa Kampanye Pemilukada Kabupaten Kuantan Singingi Tahun 2011. Jurnal Ilmu Pemerintahan Nakhoda, 12(20), 123-132. https://doi.org/http://dx.doi.org/10.3596 7/jipn.v12i20.2906

Rosidah, R. (2015). Definisi Dakwah Islamiyyah Ditinjau dari Perspektif Konsep Komunikasi Konvergensi Katherine Miller. Jurnal Qathuna, 2(2), 155-178. Retrieved from http://jurnal.uinbanten.ac.id/index.php/q athruna/article/view/9/10

Sundoro, P. (2018). STUDI KRITIS HISTORIS KOMUNIKASI MENTERI PENERANGAN HARMOKO DENGAN PERS DI ERA ORDE BARU. Jurnal Pustaka Komunikasi, l(1), 45-57. https://doi.org/https://doi.org/10.32509/ pustakom.v1i1.542

Syamsiyah, D. (2017). ANALISIS DESKRIPTIF TEORI PEMEROLEHAN BAHASA KEDUA. Jurnal Komunikasi Dan Pendidikan Islam Al-Manar, 6(2), 59-80. https://doi.org/https://doi.org/10.36668/j al.v6i2.26

Zuhro, R. S. (2019). Demokrasi dan Pemilu Presiden 2019. Jurnal Penelitian Politik, 16(1), 69-81. Retrieved from http://ejournal.politik.lipi.go.id/index.ph $\mathrm{p} / \mathrm{jpp} /$ article/view/782/541 
Vol.5 (No. 2 ) : 120- 211 Th. 2019 p-ISSN: 2502-0935 e-ISSN: 2615-6423 